\title{
PENGEMBANGAN MODEL PENDIDIKAN KARAKTER BERBASIS PENGUATAN MODAL SOSIAL BAGI MAHASISWA UIN SUNAN KALIJAGA
}

Sri Sumarni, Achmad Dardiri, Darmiyati Zuchdi

UIN Sunan Kalijaga, Universitas Negeri Yogyakarta, Universitas Negeri Yogyakarta marniuinsuka@yahoo.com, achmaddardiri@uny.ac.id, darmiyati@uny.ac.id

\begin{abstract}
Abstrak
Tujuan dari penelitian ini adalah untuk menemukan model pendidikan karakter yang sesuai dalam membangun karakter mahasiswa UIN Sunan Kalijaga. Penelitian ini dilatarbelakangi oleh merosotnya karakter mahasiswa yang disebabkan oleh city syndrome, belum siapnya mahasiswa hidup mandiri, dan kondisi yang "terkotak-kotak" karena visi spiritualitas keagamaan yang berbeda-beda. Oleh karena itu, perguruan tinggi membutuhkan "jembatan" untuk mengatasi pandangan yang merasa berbeda, yaitu melalui modal sosial yang substansinya adalah menjalin, membangun, memperkuat, dan memperkaya hubungan sesama manusia. Penelitian ini merupakan penelitian Research and Development $(R \& D)$, menggunakan analisis data model mixed method, dengan memberikan bobot lebih besar pada analisis kualitatif. Hasil implementasi model ini secara kualitatif dapat dilihat dari peningkatan aktualisasi nilai-nilai karakter para mahasiswa, baik nilai ketaatan beribadah, kepedulian, kerjasama, tanggungjawab, maupun kejujuran. Secara kuantitatif, model ini sangat efektif untuk membangun karakter kepedulian dan kerjasama, cukup efektif untuk membangun karakter ketaatan beribadah dan tanggungjawab, serta kurang efektif untuk membangun karakter kejujuran.
\end{abstract}

Kata kunci: model, pendidikan karakter, modal sosial, mahasiswa

\section{DEVELOPING A MODEL OF SOCIAL CAPITAL ENFORCEMENT-BASED CHARACTER EDUCATION FOR THE STUDENTS OF SUNAN KALIJAGA ISLAMIC STATE UNIVERSITY}

Sri Sumarni, Achmad Dardiri, Darmiyati Zuchdi

UIN Sunan Kalijaga, Universitas Negeri Yogyakarta, Universitas Negeri Yogyakarta marniuinsuka@yahoo.com, achmaddardiri@uny.ac.id, darmiyati@uny.ac.id

\begin{abstract}
The objective of the study was to find an appropriate model of character education in establishing the characters of Sunan Kalijaga State Islamic University students. The study was encouraged by the deterioriating students' characters caused by the city syndrome, the students' unpreparedness in having an independent life and the segmented condition due to the different religious-spiritual vision. Therefore, a university demands a "bridge" in order to overcome differing views by means of social capital which substances are to establish, to build, to strengthen and to enrich the association among human. The study, then, was a research and development and employed the mixed method by providing bigger loads to the qualitative analysis. The results of the model implementation might be qualitatively viewed from the improvement on the actualization of the students' character values in the domain of piety, compassion, cooperation, responsibility and honesty. Quantitatively, the model had been effective in establishing the characters of compassion and cooperation, had been quite effective in establishing the characters of piety and responsibility and had been less effective in establishing the characters of honesty.
\end{abstract}

Key words: model, character education, social capital, university students 



\section{PENDAHULUAN}

Bagi bangsa Indonesia, manifesto kultural "Bhineka Tunggal Ika" merupakan tekad untuk membentuk kohesi sosial dan integrasi sosial, serta menyiratkan landasan mutualisme (kesatuan dan kebersamaan dalam perasaan maupun perilaku) dan kerjasama yang didasarkan atas kepentingan bersama dan perasaan kebersamaan. Oleh karena itu, secara historis bangsa Indonesia dikenal sebagai bangsa yang menjunjung tinggi nilainilai kerukunan, kebersamaan, solidaritas, dan kegotongroyongan.

Di sisi lain, derasnya arus globalisasi yang diiringi dengan industrialisasi dan modernisasi telah menjadikan kesuksesan hidup lebih banyak diukur dari hal-hal yang bersifat materiil melalui apa yang disebut "taraf hidup", telah menempatkan keuntungan dan efisiensi sebagai dorongan utama bagi seseorang untuk melakukan suatu aktivitas, termasuk melakukan interaksi dan hubungan sosial. Sementara, nilai-nilai kebersamaan, gotong royong, solidaritas, kerukunan, dan keramahan sering dipandang dalam posisi yang berseberangan.

Dengan kata lain, Indonesia sedang mengalami pemudaran nilai-nilai sosial budaya. Akibatnya, konflik sosial, kekerasan, kerusuhan sosial, vandalisme, alienasi, anomie, apatisme sosial, dan kriminalitas, merupakan realitas yang semakin tampak sebagai suatu kecenderungan pada masyarakat Indonesia. Di kalangan pelajar dan mahasiswa telah terjadi dekadensi moral yang memprihatinkan. Perilaku menabrak etika, moral dan hukum dari yang ringan sampai yang berat masih sering diperlihatkan oleh pelajar dan mahasiswa. Potret buram sistem pendidikan di Indonesia tergambarkan pula pada tahun ajaran 2011/ 2012 dan 2012/2013 dengan semakin merajalela tawuran dan tindak kekerasan di kalangan pelajar dan mahasiswa. Komnas Perlindungan Anak (PA) mencatat, kasus bullying senior kepada junior masih menjadi fenomena kelam pendidikan di Indonesia pada tahun 2011. Tercatat ada sedikitnya 139 kasus bullying di lingkungan sekolah. Sementara pada awal tahun 2012, sudah ditemukan 36 kasus. Aksi bullying yang diduga terjadi di SMA Don Bosco Jakarta beberapa waktu lalu menjadi salah satu fakta.Tidak berhenti di situ, aksi tawuran dan kekerasan pelajar dan maha- siswa pun masih marak terjadi hingga menewaskan beberapa pelajar dan mahasiswa (Pratama, 2012, p.1).

Tidak jauh dari permasalahan tersebut, di UIN Sunan Kalijaga ada beberapa contoh kasus yang membutuhkan kepedulian sivitas akademika, antara lain: pertama, seorang mahasiswi UIN Sunan Kalijaga berasal dari wilayah pedesaan yang hidupnya penuh keharmonisan, kehangatan, kebersamaan, dan kepedulian. Awal-awal kuliah di Yogyakarta mengalami kesepian dan keterasingan, karena menghadapi teman-teman yang kurang peduli, kampus yang kurang peduli, bahkan temanteman kos juga kurang peduli. Karena kesepian, kompensasinya cating di internet, yang kemudian menjadi awal dari kesalahannya dalam pergaulan. Sementara pihak keluarga sama sekali tidak tahu, karena merasa telah menitipkan anaknya ke pengelola kos dan perguruan tinggi ternama (wawancara, 1 September 2012).

Kedua, seorang mahasiswa aktivis organisasi kemahasiswaan merasa frustasi karena merasa diperlakukan kurang adil dan kurang dipedulikan dalam sistem dan mekanisme Pemilwa. Pemilwa yang mestinya dapat menjadi ajang bagi para mahasiswa untuk latihan berdemokrasi, namun sering diwarnai dengan situasi ketidakadilan. Kekecewaan berujung pada terjadinya demonstrasi bersifat anarkhis yang diwarnai bentrok dengan Petugas Keamanan berakhir dengan penyegelan Gedung Rektorat dengan memasang rantai dengan gembok (Wawancara tanggal $17 \mathrm{Mei}$ 2013 dan Harian Solo Pos tanggal 18 Mei 2013).

Ketiga, seorang mahasiswi menceriterakan temannya yang sedang dipresi karena kesulitan dalam mengerjakan skripsi dan kurang mendapat bimbingan yang memadai. Dia merasa tidak ada yang mempedulikan, malu kepada teman-teman dan keluarganya, karena ketinggalan dalam mengerjakan skripsinya. Kesedihan yang berkepanjangan membuatnya sering melamun dan mengalami dipresi (Wawancara tanggal 13 April 2013).

Walaupun secara das sollen Islam sangat berkomitmen terhadap pemanfaatan modal sosial, namun dalam praktiknya belum berjalan begitu saja dan mewujud dalam perilaku keseharian umat Islam. Adanya visi spiritual keagamaan yang berbeda-beda menyebabkan penafsiran yang beragam pula 
terhadap komitmen yang dibangun tentang modal sosial. Fanatisme agama yang bersifat eksklusif sering kali bersifat kontra produktif terhadap pemanfaatan modal sosial.

Dalam sebuah komunitas Perguruan Tinggi Agama Islam (PTAI) termasuk UIN Sunan Kalijaga sering ditemukan adanya kelompok-kelompok yang berbeda visi spiritualnya yang dapat menjadi penghalang produktivitas modal sosial dan dapat menyebabkan keterasingan bagi para mahasiswa, sehingga kurang kondusif untuk pendidikan karakter.

John P. Miller telah melakukan penelitian terhadap subjek didik lebih dari tujuh tahun. Penelitian Miller menemukan bahwa siswa mengalami keterasingan di sekolah. Keterasingan siswa di sekolah ini menjadi pemicu munculnya berbagai perilaku menyimpang: tawuran, pergaulan bebas, putus sekolah, kecanduan narkoba, bahkan sampai bunuh diri. Lebih lanjut Miller menemukan bahwa salah satu sebab utama siswa mengalami keterasingan di sekolah adalah karena model pembelajaran yang melanggar nilainilai kemanusiaan bagi setiap siswa. Dari temuan-temuan penelitian tersebut, kemudian dia rancang model pendidikan yang terkenal dengan nama Humanizing The Classrom, Models of Teaching in Affective Education (Sutrisno, 2011, p.5).

Subiyantoro (2010, p.389) dalam penelitiannya yang berjudul "Pengembangan Pola Pendidikan Nilai Humanis-Religius pada Diri Siswa Berbasis Kultur Madrasah di MAN Wates 1 Kulon Progo Yogyakarta" menyimpulkan bahwa:----- dengan pola pendidikan yang memberi bimbingan atas kebebasan siswa dalam beraktualisasi diri, sikap peserta didik menjadi lebih terbuka dan dekat dengan pendidik, kreatif serta berprestasi dalam bidang yang ditekuni. Hal ini membuka peluang bagi pendidik untuk melakukan pendampingan dalam mencapai tujuan pendidikan yang lebih optimal.

Modal sosial yang substansinya menjalin, membangun, memperkuat, dan memperkaya hubungan sesama manusia dapat menjadi "jembatan" bagi "jurang" yang memisahkan kelompok-kelompok yang merasa berbeda satu sama lain. Kelompok dimaksud antara lain kaya-miskin, desa-kota, gaulkuper, "ngetren-kampungan, pondok-nonpondok, dan sebagainya, termasuk kelompok dengan perbedaan visi spiritualitas (sepertia; NU, Muhammadiyah, dan sebagainya). Modal sosial juga memperkuat kesepakatan tentang pentingnya saling percaya dan kerjasama. Modal sosial bukan hanya sekumpulan institusi yang menyangga masyarakat melalui social trust dan social norm, namun sebagai perekat sosial (social glue) yang menggerakkan masyarakat untuk bersama-sama mencapai tujuan bersama.

Penelitian ini bermaksud menjawab masalah berikut antara lain: (1) karakter mahasiswa UIN Sunan Kalijaga Yogyakarta; (2) upaya yang dilakukan oleh UIN Sunan Kalijaga dalam membangun karakter mahasiswanya; (3) model pendidikan karakter seperti apa yang sesuai diterapkan untuk membangun karakter mahasiswa UIN Sunan Kalijaga; dan (4) keefektifan model tersebut.

\section{METODE PENELITIAN}

Penelitian ini merupakan penelitian Research and Development (R \& D), untuk menghasilkan sebuah produk berupa: "model pendidikan karakter berbasis penguatan modal sosial bagi mahasiswa UIN Sunan Kalijaga". dan akan menguji kefektifan dari produk tersebut. Rancangan penelitian mengacu pada pendapat Borg and Gall (1983, p.772) yang terdiri dari 7 tahap: (1) melakukan analisis kebutuhan untuk melihat adanya problem; (2) mencari penyebab terjadinya masalah; dan (3) menggunakan hasil penelitian untuk menentukan solusi yang relevan dengan produk yang akan dihasilkan; (4) mengembangkan produk didasarkan pada temuan hasil penelitian; (5) melakukan uji validasi produk melalui diskusi dengan pakar/ahli; (6) melakukan tes lapangan dimana produk akan digunakan; dan (7) mengadakan revisi sehingga produk sesuai dengan kriteria atau tujuan yang telah ditentukan.

Penelitian ini dilaksanakan pada tahun 2013-2014, bertempat di UIN Sunan Kalijaga. Subjek penelitian ini meliputi sivitas akademika: Pimpinan Universitas, Pimpinan Fakultas, Pimpinan Program Studi, Dosen, Mahasiswa, dan Pegawai.

Data yang diperoleh dalam penelitian ini merupakan data kualitatif dan kuantitatif. Data kualitatif dikumpulkan melalui wawancara mendalam, observasi, dan studi dokumen, dengan menggunakan pedoman wawan- 
cara, pedoman observasi, sedangkan data kuantitatif dikumpulkan dengan angket.

Data kualitatif dianalisis menurut Miles and Huberman dengan langkah-langkah: organisasi data, reduksi data, penyajian data, dan penarikan kesimpulan. Teknik analisis data kuantitatif yang digunakan adalah Structural Equational Model (SEM) dan Analisis trend karakter mahasiswa.

\section{HASIL PENELITIAN DAN PEMBAHASAN}

\section{Masalah Karakter Mahasiswa UIN Sunan Kalijaga}

"Keterasingan" peserta didik sejak masa sekolah masih terus berlanjut sampai jenjang pendidikan tinggi. Termasuk hal ini adalah para mahasiswa yang sedang beradaptasi: (1) dari sistem pendidikan pedagogis ke sistem pembelajaran andragogis, (2) dari kehidupan yang bergantung pada orang tua ke kehidupan mandiri, (3) dari daerah pedesaan ke perkotaan, di mana dampak dari arus globalisasi lebih kuat menerpa mereka. Di samping itu, lingkungan pendidikan pada perguruan tinggi lebih bersifat multikultur daripada lingkungan pendidikan sebelumnya, baik di lingkungan kampus maupun lingkungan masyarakat sekitarnya. Lingkungan demikian menyajikan nilai-nilai budaya yang kadang saling berbenturan satu sama lain.

Kondisi tersebut dapat membuat mahasiswa mengalami kebingungan, yang kemudian berlanjut pada gejolak mental yang rentan terhadap pengaruh ke mana arus membawa mereka. Pada gilirannya para mahasiswa dapat menunjukkan sikap labil dan mudah putus asa, mudah berbuat anarkhis, mengkonsumsi narkotika, minum minuman keras, pergaulan bebas, bahkan pembunuhan ataupun bunuh diri. Dengan kata lain para mahasiswa baru sedang mengalami cultural shock.

Oleh karena itu, mahasiswa membutuhkan "jembatan" untuk menuju kemandirian. "Jembatan" dimaksud adalah pendidikan yang memberi penguatan modal sosial yang mampu mengatasi keterasingan, kesepian, bahkan juga rasa frustasi. Mereka membutuhkan pendidikan yang penuh "kehangatan", rasa saling percaya, kepedulian, kebersamaan, dan juga kerukunan.

Dari hasil angket yang disebar terhadap 80 mahasiswa yang masih duduk pada tahun pertama kuliah juga diperoleh fakta antara lain: rendahnya kemampuan mahasiswa dalam hal pengendalian diri (mudah terbawa arus), kurang dapat menahan marah dan kecewa, kurang dapat menerima kritikan, dan sebagainya, sebagaimana dapat dilihat pada Tabel 1.

Tabel 1. Skor Kepemilikan Modal Sosial Melekat Sifat Pribadi

\begin{tabular}{|c|c|c|c|c|}
\hline No & $\begin{array}{l}\text { No } \\
\text { Butir }\end{array}$ & Uraian & Skor & Nilai \\
\hline 1 & 28 & $\begin{array}{l}\text { Menjadi pendengar yang baik } \\
\text { (tidak mendominasi } \\
\text { pembicaraan }\end{array}$ & 280 & 70 \\
\hline 2 & 45 & $\begin{array}{l}\text { Kemampuan menahan rasa } \\
\text { kecewa }\end{array}$ & 274 & 68.5 \\
\hline 3 & 56 & $\begin{array}{l}\text { Memiliki wawasan tentang } \\
\text { resiko dari pergaulan bebas }\end{array}$ & 273 & 68.25 \\
\hline 4 & 23 & $\begin{array}{l}\text { Tidak merasa bersalah ketika } \\
\text { tidak bisa membantu teman } \\
\text { yang membutuhkan }\end{array}$ & 273 & 68.25 \\
\hline 5 & 37 & $\begin{array}{l}\text { Kebiasaan tidak banyak } \\
\text { menuntut haknya }\end{array}$ & 272 & 68 \\
\hline 6 & 57 & $\begin{array}{l}\text { Memiliki wawasan tentang } \\
\text { resiko narkoba atau minum } \\
\text { minuman keras }\end{array}$ & 271 & 67.75 \\
\hline 7 & 51 & $\begin{array}{l}\text { Kemampuan menolak ajakan } \\
\text { teman ke mall/café }\end{array}$ & 260 & 65 \\
\hline 8 & 41 & $\begin{array}{l}\text { Kebiasaan mengajak teman } \\
\text { untuk membantu orang lain }\end{array}$ & 257 & 64.25 \\
\hline 9 & 9 & $\begin{array}{l}\text { Kemampuan tidak } \\
\text { menceritakan kejelekan teman }\end{array}$ & 256 & 64 \\
\hline 10 & 58 & $\begin{array}{l}\text { Kebiasaan mengajak teman } \\
\text { untuk diskusi dan belajar }\end{array}$ & 254 & 63.5 \\
\hline 11 & 31 & Kesediaan menerima kritik & 254 & 63.5 \\
\hline 12 & 3 & $\begin{array}{l}\text { Berusaha mendahului kenalan } \\
\text { dengan teman kuliah }\end{array}$ & 251 & 62.75 \\
\hline 13 & 50 & $\begin{array}{l}\text { Kemampuan menahan diri dari } \\
\text { ajakan teman untuk main }\end{array}$ & 249 & 62.25 \\
\hline 14 & 42 & Kemampuan menahan marah & 240 & 60 \\
\hline
\end{tabular}

Sumber: Hasil skoring dan penilaian angket Modal Sosial Melekat Sifat Pribadi (April 2013)

Empat belas butir angket pada tabel di atas adalah skor terendah kecakapan sosial para mahasiswa UIN Sunan Kalijaga dari keseluruhan butir angket berjumlah 60 buah. Skor paling rendah adalah kemampuan para mahasiswa dalam menahan marah yang hanya memperoleh skor 240 dari 400 skor maksimal dan kemampuan menahan diri dari ajakan teman untuk bermain dengan skor 62,25. Secara kualitatif dapat dimaknai data di atas menunjukkan masih rendahnya modal sosial 
yang melekat sifat pribadi mahasiswa atau dengan kata lain kecakapan sosial sebagian besar mahasiswa termasuk dalam kategori kurang dan rendah (55\%), lihat grafik pada Gambar 1.

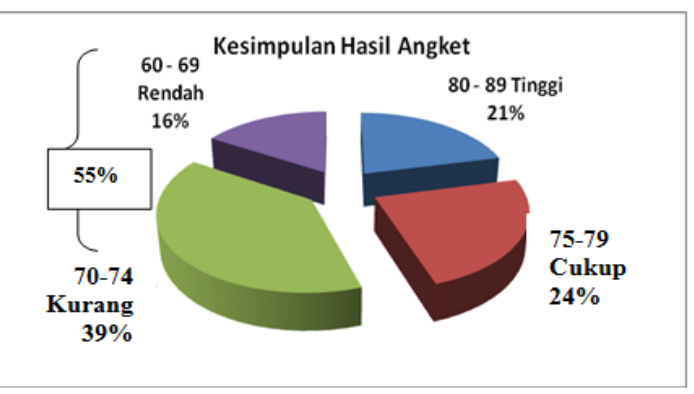

Gambar 1. Kesimpulan Hasil Angket tentang Karakter Bersosial Mahasiswa

Perhitungan skor angket dari sisi subjek penelitian sebanyak 80 orang mahasiswa dengan skor ideal 300 dapat diperoleh skor rata-rata 227 atau nilai 75,63 dengan standar mutlak. Sebanyak 13 orang mahasiswa memperoleh skor di bawah 210 dari 300 skor maksimal atau nilai di bawah 70 dan sebanyak 31 orang memperoleh skor di bawah 225 dari skor maksimal 300 dengan nilai di bawah 75 . Ini menunjukkan bahwa sebagian besar mahasiswa belum memiliki kecakapan sosial yang memadai. Fenomena ini terjadi pada mahasiswa di lingkungan PTAI yang notabene sebagai perguruan tinggi yang berkomitmen di bidang religiusitas.

Di sisi lain dapat dikemukakan sebuah analisis bahwa kebebasan dan hidup mewah merupakan salah satu orientasi para mahasiswa yang sekarang semakin marak di kota-kota besar, termasuk Yogyakarta. Bahkan sebagian mahasiswa menginginkan dirinya bebas dari setiap aturan yang tidak sesuai dengan keinginannya, walaupun peraturan tersebut menguntungkan dirinya, misalnya peraturan tentang perkuliahan di UIN Sunan Kalijaga yang harus berjumlah minimal $75 \%$. Mereka umumnya menolak peraturan positif karena menganggap dirinya terbelenggu.

Hasil identifikasi masalah mahasiswa UIN Sunan Kalijaga adalah: pertama seringnya terjadi demo anarkhis, bahkan bila diratarata sekitar 2 kali per bulan. Bermacam-macam motif mereka, mulai dari kenaikan BBM, kehadiran kuliah 75\%, kenaikan SPP, penarikan biaya training bahasa, penarikan biaya user education di perpustakaan, PEMILWA, dan sebagainya. Tindakan mereka pun bermacam- macam, ada yang membakar ban di dalam gedung, memecah kaca, merusak pintu, menyegel pintu ruang kuliah, dan sebagainya. Kedua adanya pergaulan bebas, bahkan ada beberapa yang mengalami kehamilan dan harus putus kuliah; Ketiga, beberapa mahasiswa juga terjebak pada mabuk-mabukan (narkotika, minum minuman keras) dan pecandu rokok, Keempat, adanya friksi (golongan) karena perbedaan visi spiritualitas di kampus, misalnya PMII, HMI, KAMMI, dan sebagainya, Kelima beberapa mahasiswa ada yang main kartu, "kongko-kongko" di taman, halaman, tempat parkir, Keenam masih ada beberapa mahasiswa yang kurang peduli, kurang sopan/cuek, dan sebagainya, Ketujuh bahkan ada juga yang meninggalkan sholat wajib dan sholat Jum'at.

Adapun penyebab terjadinya masalah tersebut, antara lain karena lemahnya kontrol sosial, ketidaksiapan hidup mandiri, keterasingan, city syndrome, kondisi lingkungan yang tidak kondusif, radius of trust yang sempit, dan sebagainya. Dari penyebab terjadinya masalah itulah perlu dirancang model pendidikan karakter yang tepat untuk memberikan alternatif solusinya.

\section{Model Pendidikan Karakter yang telah Ada}

Terkait dengan pembentukan karakter mahasiswa, UIN Sunan Kalijaga belum sepenuhnya focus dan terencana secara matang. Namun memiliki harapan, melalui sosialisasi pembelajaran (SosPem) diharapkan mahasiswa mampu disiplin, semangat, kerja keras dalam pencapaian prestasi belajar atau prestasi akademik. Melalui Kuliah Kerja Nyata $(\mathrm{KKN})$ diharapkan mahasiswa memiliki kemampuan beradaptasi dengan masyarakat luas. Namun hasilnya dapat dicermati bahwa melalui 2 program tersebut karakter mahasiswa belum tercapai secara totalitas (masih maraknya demo anarkhis, pergaluan bebas, narkotika, minum minuman keras, plagiasi, dsb). UIN Sunan Kalijaga Yogyakarta masih terus berbenah diri dalam membangun karakter mahasiswa dengan ciri khas seperti yang telah diuraikan di atas.

Peneliti memformulasikan dan mengonsepkan pendidikan karakter yang telah dilakukan di UIN Sunan Kalijaga saat kini. Istilah yang diangkat dalam melakukan konsep ini adalah existing model (model yang telah ada) di UIN Sunan Kalijaga Yogyakarta. 


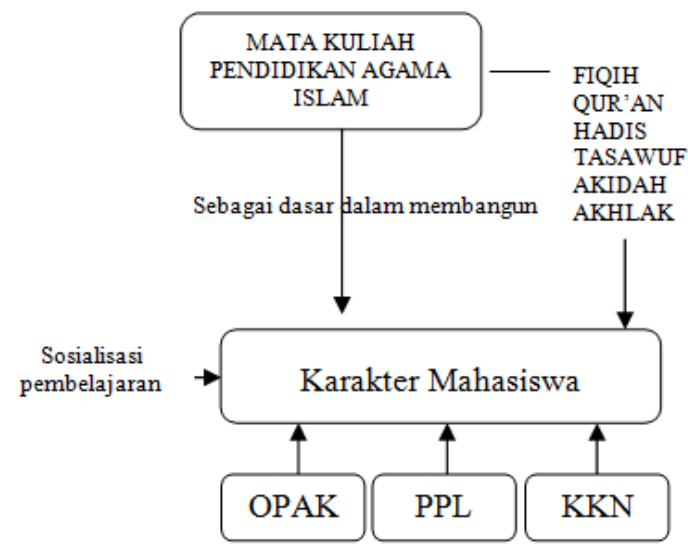

Gambar 2. Model Pendidikan Karakter yang Telah Ada di UIN Sunan Kalijaga

UIN Sunan Kalijaga sampai saat kini, berfokus pada pembangunan fondasi karakter melalui kurikulum mata kuliah rumpun pendidikan agama Islam. Diasumsikan bahwa dengan membentuk fondasi karakter diharapkan karakter mahasiswa akan terbangun. Namun, capaian hasil pendidikan agama di UIN Sunan Kalijaga sampai saat kini cenderung lebih besar pada domain kognitif (pidato rektor pada pengukuhan guru profesional, 30 Oktober 2013). Keseimbangan antara domain kognitif dan afektif serta perilaku belum sepenuhnya proporsional (baca sering terjadi demonstrasi anarkhis yang dilakukan oleh mahasiswa UIN Sunan Kalijaga).

Di balik kekurangan yang dimiliki tersebut, UIN Sunan Kalijaga memiliki potensi yang besar untuk berkembang menjadi perguruan tinggi Papan Atas. Hal ini pernah disampaikan oleh Dirjen Pendidikan Islam Kementerian RI Tahun 2012 yang waktu itu masih dijabat oleh Prof. Dr. Mohammad Ali, bahwa ada tiga PTAIN yang diharapkan dalam waktu dekat menjadi perguruan tinggi Papan Atas, yaitu: UIN Syarif Hidayatullah Jakarta, UIN Sunan Kalijaga Yogyakarta, dan UIN Malik Ibrahim Malang.

UIN Sunan Kalijaga memiliki ciri khas yang menjadi jargon dalam pengembangan akademiknya selama ini yaitu paradigma integrasi dan interkoneksi. Paradigma integrasi dan interkoneksi ini menjadi lebih bermakna seiring transformasi IAIN menjadi UIN Sunan Kalijaga pada Tahun 2004. Filosofi dari Paradigma ini terkandung dalam Visi UIN Sunan Kalijaga, yaitu: "Unggul dan terkemuka dalam pemaduan dan pengembangan keislaman dan keilmuan bagi peradaban".
Paradigma integrasi dan interkoneksi tersebut telah memberikan landasan yang kuat dalam pengembangan akademik dan keilmuan, baik dalam pengembangan kurikulum, pembelajaran, maupun penelitian. Paradigma ini bermaksud menjelaskan bahwa agama dan ilmu saling terkait, saling menyapa, dan bahkan saling mengisi, digambarkan seperti jaring laba-laba berikut ini (LPJ Rektor 20012005, pp.53-54).

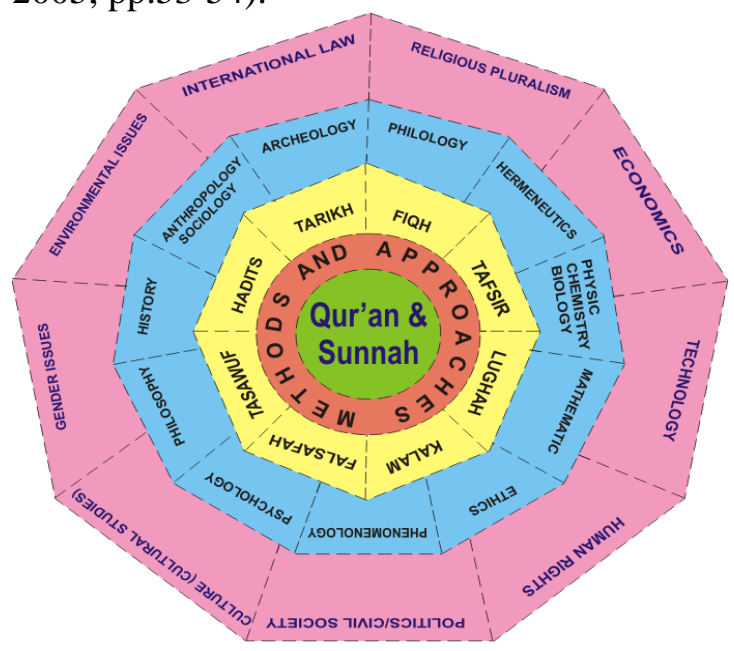

Gambar 3. Jaring Laba-laba IntegrasiInterkoneksi Pengembangan Keilmuan di UIN Sunan Kalijaga

Paradigma tersebut menjadi landasan yang kokoh bagi UIN Sunan Kalijaga untuk mengembangkan keilmuaan melalui Tri Dharma Perguruan Tinggi, yaitu: pendidikan, penelitian, dan pengabdian kepada Masyarakat.

Untuk mewujudkan misinya tersebut, UIN Sunan Kalijaga telah berusaha keras untuk melaksanakan tata kelola yang baik dan bersih atau good university governance. Hal ini diwujudkan dengan menerapkan penjaminan mutu akademik melalui Lembaga Penjaminan Mutu (LPM) dan pola keuangan dengan sistem Badan Layanan Umum (BLU), serta mendeklarasikan diri sebagai Kawasan Bebas Korupsi sejak tahun 2012 di bawah kepemimpinan Bapak Prof. Dr. Musa Asy'arie. Sebagai wujud dari upaya tersebut, UIN Sunan Kalijaga dapat mencapai Peringkat Tertinggi dalam Akreditasi Institusi berdasarkan SK BAN PT No.283/SK/BAN-PT/ VIII/2014 yaitu A, serta telah memiliki standar ISO 2008-9001 dari TUV Jerman. Di samping itu, dalam manajemen perpustakaannya, UIN Sunan Kalijaga telah menjadi tiga besar perguruan tinggi dengan pengelolaan terba- 
gus, pernah mendapat anugerah rekor MURI dalam hal penggunaan gelombang RFId ( $R a-$ dio Frequncy Identified) dalam pengembalian buku/koleksinya.

Dengan adanya kelebihan-kelebihan tersebut, maka implementasi model pendidikan karakter yang dikembangkan oleh peneliti menjadi mungkin untuk dilaksanakan.

\section{Desain Model Hipotetik}

\section{Nilai- Nilai Karakter yang Dikembangkan}

Mengacu pada tahapan perkembangan moral menurut Kohlberg, mahasiswa dengan usia antara 19 - 24 tahun, telah memasuki tingkat pasca-konvensional di mana moral yang terinternalisasi tidak berdasarkan standar orang lain namun sudah menggunakan prinsip yang diyakininya sendiri. Tingkatan ini berorientasi pada 'kontrak sosial' dan 'prinsip etika universal'. Pada tingkat kontak sosial seseorang sudah memiliki kesadaran bahwa setiap orang memiliki nilai dan pendapat yang berbeda, namun juga menyadari adanya nilai-nilai kelompok dan berusaha mengikuti kesepakatannya. Adapun pada tahap yang paling tinggi yakni orientasi prinsip etika universal, prinsip moral seseorang dilandasi oleh prinsip-prinsip universal seperti keadilan dan hak-hak azasi manusia. Karakteristik moral seperti ini biasanya dialami oleh individu yang sudah berusia dua puluh tahun ke atas. Seseorang yang menunjukkan moralitas pascakonvensional (postconventional morality) memandang peraturan sebagai mekanisme yang bermanfaat namun dapat diubah demi menjaga stabilitas sosial secara umum dan melindungi hak-hak manusia. Peraturan bukanlah prinsip-prinsip absolut yang harus dipatuhi tanpa dipertanyakan. Para individu dengan moral pasca-konvensional hidup dengan prinsip-prinsip abstrak mereka sendiri tentang yang benar dan yang salah. Mereka bisa saja melanggar peraturan yang tidak sesuai dengan prinsip-prinsip mereka (Borba, 2001, p.21).

Berkaitan dengan perkembangan moral tersebut, terdapat nilai-nilai dasar moral yang dapat membantu seseorang untuk bersikap sesuai moral dalam menghadapi tekanan lingkungan yakni religiusitas, tanggung jawab, kepedulian, dan kerja sama. Dari nilainilai tersebut bagi mahasiswa UIN Sunan Kalijaga yang memiliki permasalahan sebagaimana telah disebutkan, yaitu: (1) masalah demo anarkhis dan friksi kampus membutuhkan pengembangan nilai kepedulian dan tanggung jawab, (2) masalah plagiasi dan mencontek membutuhkan nilai kejujuran dan tanggung jawab, (3) masalah tidak tertib shalat, minum-minuman keras, narkotika, dan pergaulan bebas membutuhkan pengembangan nilai ketaatan beribadah, masalah "keterasingan" membutuhkan pengembangan nilai kepedulian dan kerjasama. Jadi, nilai-nilai karakter yang dikembangkan dalan studi ini adalah nilai ketaatan beribadah, kejujuran, tanggung jawab, kepedulian, dan kerjasama.

Nilai-nilai karakter yang ditargetkan melalui sebuah program bisa saja hanya merupakan nilai-nilai secara eksplisit. Dengan kata lain, terdapat banyak nilai karakter yang secara bersama-sama turut serta di dalamnya sebagai dampak pengiring. Namun untuk memudahkan pelaksanaan, program-program pendidikan karakter, khususnya Program Pendidikan Karakter Berbasis Penguatan Modal Sosial dalam studi ini hanya dikembangkan nilai-nilai tertentu saja yang dianggap sebagai nilai-nilai luhur universal.

\section{Konsep Dasar Model}

Model pendidikan karakter yang digunakan dalam studi ini dimaksudkan sebagai deskripsi program pendidikan untuk mengembangkan nilai-nilai pembangun karakter. Deskripsi tersebut mulai dari konsep dasar, komponen model, pendekatan, metode, sampai strategi, dan evaluasi, baik selama proses maupun hasil belajar pendidikan karakter.

Pada setiap komunitas, biasanya terdapat nilai-nilai sosial tertentu yang mendominasi ide yang berkembang. Dominasi ide tertentu dalam masyarakat akan membentuk dan menentukan aturan-aturan bertindak masyarakatnya (the rules of conducts) dan aturan-aturan bertingkah laku (the rules of behaviors) yang membentuk pola-pola kultural (cultural pattern). Nilai-nilai individualistik, curiga, dan konflik yang berkembang di masyarakat dapat mereduksi potensi modal sosial yang berkembang di masyarakat tersebut. Sedangkan nilai kebersamaan, tenggang rasa, dan penghormatan yang berkembang dalam masyarakat akan dapat menguatkan potensi modal sosial yang ada di masyarakat tersebut. 
Melalui aneka ikatan horizontal modal sosial berperan dan dibutuhkan untuk memberi masyarakat suatu sence identitas dan tujuan bersama. Modal sosial merangkai berbagai aset sosial, psikologis, kultural, kognitif, dan institusinal yang dapat meningkatkan perilaku kooperatif yang saling menguntungkan. Bahkan tidak saja menjadi perekat, modal sosial dengan social trust dan social norm dalam jejaring sosial dapat dimanfaatkan untuk memecahkan berbagai masalah (common problem) secara bersama dalam pola hubungan timbal balik (resiprocity).

Dalam konteks inilah peran modal sosial dalam pendidikan memegang peranan penting untuk membangun kecakapan sosial. Konsep modal sosial menjadi komponen penting untuk membangun karakter mahasiswa, karena menempatkan manusia sebagai subyek penting dalam penyelenggaraan pendidikan. Ada dua kelompok definisi tentang modal sosial yang diberikan oleh para pakar. Kelompok pertama lebih menekankan pada aspek jejaring hubungan sosial yang diikat oleh rasa kesalingpercayaan (trust), kepemilikan informasi, saling memahami, saling mendukung, dan kesamaan nilai, serta komitmen yang sama terhadap norma. Sedangkan kelompok kedua menekan aspek kepemilikan modal sosial pada sifat pribadi yang dimiliki oleh para anggota kelompok masyarakat yang memugkinkan terjalinnya kerja sama diantara mereka.

Pendapat kelompok pertama diwakili oleh berbagai teori dinamika kelompok yang melihat modal sosial sebagai suatu kelompok atau komunitas yang memiliki ciri kohesivitas tinggi yang disebut sebagai Modal Sosial Melekat pada Lembaga, sedangkan kelompok kedua diwakili oleh teori kepribadian (traits theorist) yang melihat bahwa munculnya suatu kelompok yang kohesif baru akan terjadi kalau individu memiliki sifat kepribadian tertentu yang mendukungnya untuk berinteraksi dengan orang lain (Ancok, 2003, p.17). Dengan kata lain definisi kedua lebih menekankan pada sifat pribadi yang melekat (embedded) pada diri manusia yang terlibat dalam sebuah interaksi sosial, yang terdiri dari: sifat mental berkelimpahan, pikiran positif kepada orang lain, kemampuan berempati, memiliki sikap terbuka, komunikasi transformasional, berorientasi win win solution, sifat melayani, kebiasaan apresiatif, dan pengen- dalian diri. Definisi kelompok kedua ini disebut sebagai Modal Sosial Melekat Sifat Pribadi.

Dalam konteks penelitian ini, definisi kelompok pertama yaitu modal sosial yang melekat pada lembaga digunakan sebagai dasar untuk membangun konsep model secara menyeluruh yang mencakup empat dimensi, yaitu: dimensi caring adalah saling peduli, saling memahami, berpikir positif, kepemilikan informasi; dimensi sharing adalah saling percaya, saling berbagi, saling mendukung, dan saling kerja sama internal; dimensi networking adalah keterbukaan dan saling kerja sama eksternal; dan dimensi problem solving adalah saling memfasilitasi dalam pencarian solusi dari permasalahan yang dihadapi oleh anggota masyarakat dan pengendalian diri untuk tidak memunculkan masalah dalam komunitas). Definisi modal sosial yang diberikan oleh kelompok pertama ini dapat disebut Modal Sosial Struktural atau Melekat pada Lembaga, sebagaimana terlihat pada gambar berikut ini.

Sementara definisi kelompok kedua yang melekat sifat pribadi digunakan untuk mensistematisasi modul pendidikan karakter berbasis modal sosial. Hal ini berdasarkan asumsi bahwa pembangunan karakter dipengaruhi oleh banyak faktor yaitu: faktor bawaan (nature) dan lingkungan (nurture) dimana orang yang bersangkutan tumbuh dan berkembang. Jadi usaha pembangunan karakter peserta didik dapat dilakukan melalui: (1) pengembangan sifat pribadi dan (2) rekayasa faktor lingkungan.

\section{Pendekatan}

Pendekatan pendidikan karakter adalah cara untuk mengatasi masalah dalam pendidikan karakter atau untuk mencapai tujuan pendidikan karakter. Strategi tunggal tampaknya sudah tidak cocok lagi, apalagi yang bernuansa indoktrinatif. Pemberian teladan saja juga kurang efektif diterapkan, karena sulitnya menentukan yang paling tepat untuk dijadikan teladan. Dengan kata lain, diperlukan multi pendekatan atau yang oleh Kirschenbaum (1995) dalam Zuchdi, 2013, p. 32) disebut pendekatan komprehensif. Istilah komprehensif yang digunakan dalam pendidikan karakter berbasis penguatan modal sosial sedikit berbeda dengan pendekatan 
yang dikembangkan Kirschenbaum, walaupun istilahnya sama.

Pendekatan pendidikan karakter dalam studi ini mengacu pada pendekatan dalam kajian modal sosial yang secara garis besar ada tiga aras utama, yaitu: pendekatan mikro atau modal sosial kognitif (cognitive social capital), pendekatan meso atau modal sosial struktural (structural social capital), dan pendekatan makro (institutional social capital). Pendekatan mikro yang mencakup kajian tentang potensi masing-masing individu untuk melakukan kerjasama dijadikan dasar untuk mengkaji modal sosial sebagai sifat yang embedded pada diri individu. Hal ini selaras dengan nilai inti yang melandasi modal sosial kognitif adalah civic engagement, yaitu suatu "perjumpaan antar warga yang dilandasi oleh pertautan emosional mendalam, hubungan yang hangat, perasaan dekat secara psikologis, dan ikatan solidaritas yang terbangun atas dasar empati dan persaudaraan universal" (Barliana, 2011, pp.5-6)

Pendekatan Meso menekankan pada struktur-struktur yang lebih bersifat instrumental, yang memudahkan terjadinya kerja sama dalam suatu komunitas melalui pembuatan aturan, prosedur, struktur organisasi, dan pembiasaan-pembiasaan yang menjadi komitmen bersama (kultur lembaga), contohnya: aturan-aturan perilaku (code of conduct) kampus, adanya tata tertib mahasiswa, kode etik dosen, tugas dan fungsi Pembimbing Akademik, dan SOP Pelayanan kepada Mahasiswa. Pendekatan Meso dalam penelitian ini berupa kebijakan, peraturan, dan kebiasaankebiasaan yang diberlakukan untuk membangun kultur lembaga yang menyuburkan modal sosial, menurut Ancok 2003 terdiri dari: kebijakan yang membuat komunitas bebas dari rasa takut, bebas dari penindasan, anti deskriminatif, penuh kepedulian, saling silaturahmi dan kerjasama.

Sedangkan pendekatan makro berfokus pada kondisi-kondisi yang bersifat positif bagi penciptaan jejaring kerjasama, khususnya dengan pihak luar yang terkait, misalnya antara lembaga pendidikan dengan keluarga dan masyarakat. Kegiatannya bisa dilakukan dengan membangun dan memperkuat jejaring kerjasama antara dua kelompok atau instansi atau lebih untuk menumbuhkan rasa saling percaya, saling peduli, dan saling kerjasama, misalnya membuat forum silaturahmi antara mahasiswa, orang tua dengan program studi/ jurusan/fakultas/ universitas.

Ketiga pendekatan tersebut sebagaimana disajikan pada Gambar 4.

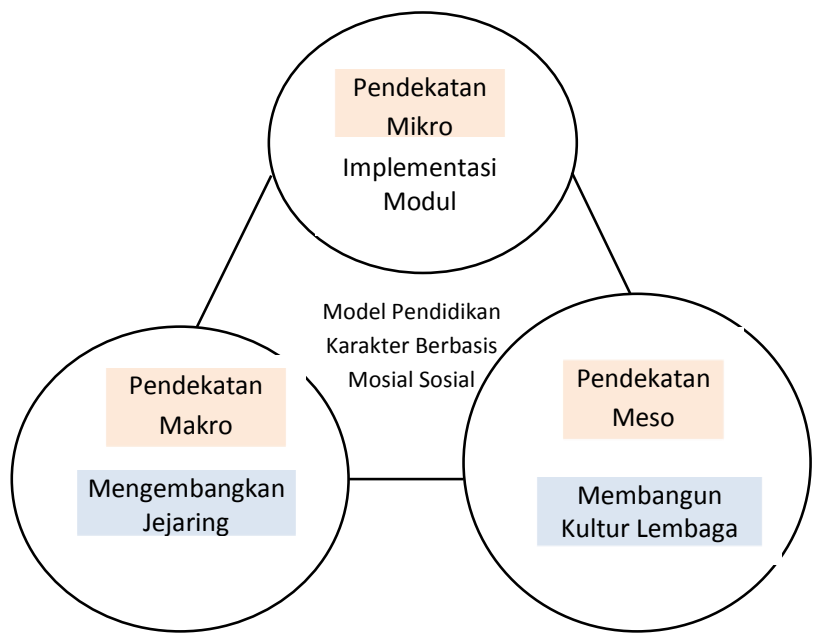

Gambar 4. Pendekatan Pendidikan Karakter Berbasis Penguatan Modal Sosial

Melalui berbagai pendekatan tersebut, para mahasiswa di lingkungan PTAI yang kebanyakan jauh dari kekuarga perlu terus dipupuk modal sosialnya agar tidak merasa hampa, terasing, terkucilkan, yang bisa membuat mereka putus asa dan melakukan hal-hal yang di luar akal sehatnya seperti: demo anarkhis, pecandu narkotika, minum minuman keras, pergaulan bebas, terorisme, dan sebagainya. Itulah sebabnya UIN Sunan Kalijaga membangun lembaganya dengan visi "rahmatan lil'alamiin".

\section{Ringkasan Isi Modul}

Definisi modal sosial menurut Fukuyama mengandung ajaran berbuat baik kepada sesama manusia dan lima aspek nilai (value) yang dikemukakan oleh Schwartz (1994) dalam Ancok (2003), yakni: universalism adalah nilai tentang pemahaman terhadap orang lain: (1) apresiasi, toleransi, serta peduli terhadap manusia dan makhluk ciptaan Tuhan lainnya ; (2) benevolence adalah nilai tentang pemeliharaan dan peningkatan kesejahteraan orang lain; (3) tradition adalah nilai yang mengandung penghargaan, komitmen, dan penerimaan, terhadap tradisi dan gagasan budaya tradisional; (4) conformity adalah nilai yang terkait dengan pengekangan diri terhadap dorongan dan tindakan yang merugikan orang lain, serta (5) security adalah nilai yang 
mengandung keselamatan, keharmonisan, kestabilan masyarakat dalam berhubungan dengan orang lain dan memperlakukan diri sendiri. Lima macam nilai sosial yang melekat pada seseorang tersebut dapat menjadi perekat sosial (social glue) dalam masyarakat yang sangat dibutuhkan pada era globalisasi, di mana teknologi informasi telah melunturkan hubungan antar manusia.

Bila kelima macam nilai dari Schwartz tersebut diintergrasikan dengan ajaran berbuat baik dalam Al Qur'an Hadist, maka istilah yang digunakan dalam penelitian ini dapat dilihat pada Tabel 2.

Tabel 2. Sintesis Nilai-nilai Sosial Schwartz dengan Ajaran Islam

\begin{tabular}{|c|c|c|c|}
\hline $\begin{array}{c}\text { Dimensi Nilai } \\
\text { Sosial Schwartz }\end{array}$ & Definisi & Ajaran Islam & $\begin{array}{c}\text { Istilah } \\
\text { Populer }\end{array}$ \\
\hline Tradition & $\begin{array}{l}\text { nilai yang mengandung } \\
\text { penerimaan, penghargaan, } \\
\text { dankomitmen terhadap tradisi dan } \\
\text { gagasan budaya tradisional }\end{array}$ & $\begin{array}{l}\text { Di UIN, nilai komitmen hamba kepada } \\
\text { Allah sebagai bentuk ketaqwaan adalah } \\
\text { tradisi yang dibangun sejak lembaga ini } \\
\text { didirikan }\end{array}$ & Integrity \\
\hline Universalism & $\begin{array}{l}\text { nilai apresiasi, toleransi, serta } \\
\text { proteksi terhadap manusia dan } \\
\text { makhluk ciptaan Tuhan lainnya }\end{array}$ & $\begin{array}{l}\text { Islam sangat menghargai } \\
\text { keberagaman, maka saling peduli } \\
\text { adalah kebesaran jiwa dan majunya } \\
\text { peradaban }\end{array}$ & Caring \\
\hline Benevolence & $\begin{array}{l}\text { nilai tentang pemeliharaan dan } \\
\text { peningkatan kesejahteraan orang } \\
\text { lain }\end{array}$ & $\begin{array}{l}\text { Di dalam harta seorang muslim } \\
\text { terkandung haknya mereka yang } \\
\text { membutuhkan }\end{array}$ & Sharing \\
\hline Security & $\begin{array}{l}\text { nilai yang mengandung } \\
\text { keharmonisan dan kestabilan } \\
\text { masyarakat dalam berhubungan } \\
\text { dengan orang lain }\end{array}$ & $\begin{array}{l}\text { Manusia diciptakan untuk saling "kenal } \\
\text { mengenal" (dalam arti yang } \\
\text { sesungguhny) }\end{array}$ & Networking \\
\hline Conformity & $\begin{array}{l}\text { nilai yang terkait dengan } \\
\text { pengekangan diri terhadap } \\
\text { dorongan dan tindakan yang } \\
\text { merugikan orang lain }\end{array}$ & $\begin{array}{l}\text { Allah bersama orang yang sabar, dan } \\
\text { pengendalian diri adalah kekuatan dari } \\
\text { pemecahan masalah }\end{array}$ & $\begin{array}{l}\text { Problem } \\
\text { Solving }\end{array}$ \\
\hline
\end{tabular}

Tabel 3. Dimensi dan Indikator Modal Sosial

\begin{tabular}{ll}
\hline \multicolumn{1}{c}{ DIMENSI } & \multicolumn{1}{c}{ INDIKATOR } \\
\hline \multirow{2}{*}{ INTEGRITY } & 1. Bersyukur \\
& 2. Ketaatan Beribadah \\
& 3. Pengembangan Diri \\
1. Pikiran Positif & 2. Empati \\
CARING & 1. Mental Berkelimpahan \\
& 2. Sifat Melayani \\
SHARING & 3. Kebiasaan Apresiasi \\
& 1. Sifat Terbuka \\
& 2. Komunikasi \\
NETWORKING & Transformasional \\
& 1. Pengendalian Diri \\
& 2. Win-win Solution \\
\hline
\end{tabular}

Dalam konteks penelitian ini kelima dimensi nilai sosial Schwartz tersebut mendapat ruh dari nilai-nilai Al Qur'an dan Hadis. Peneliti melakukan penjabaran dari kelima dimensi tersebut ke dalam 11 indikator, dimana 7 diantaranya mengambil dari bukunya Ancok (2003, pp.18-20) yang selanjutnya diintegrasikan dengan nilai-nilai sosial yang bersumber dari Al Qur'an Hadis. Uraian indikator setiap dimensi modal sosial, dijelaskan secara rinci pada Tabel 3.

Validasi Ahli terhadap Model

Uji validasi konsep dasar model, struktur dan komponen model, isi komponen model, dan indikator keberhasilan masingmasing variabel dari model hipotetik dalam penelitian ini menggunakan teknik expert judgment yang dilakukan melalui kegiatan focus group discussion/FGD. Kegiatan FGD ini melibatkan para ahli yang memiliki kualifikasi dalam bidang pendidikan karakter, pendidikan Islam, modal sosial (sosiologi dan 
psikologi), bahasa Indonesia, kurikulum, dan metodologi $R \& D$ ).

Karakteristik ahli yaitu orang yang memiliki kompetensi sesuai dengan bidangnya dan kinerja yang baik. Dalam forum FGD, para ahli menjastifikasi konsep, struktur dan komponen model yang dirancang peneliti. Dalam melakukan jastifikasi, para ahli melakukan evaluasi dan penilaian terhadap model yang dikembangkan. Yang dihasilkan dari kegiatan validasi ini adalah masukan atas konsep dasar, struktur dan komponen model, isi komponen model, dan sistem model, untuk perbaikan model yang dikembangkan yaitu model final.

Hasil FGD dengan pakar tersebut dapat disimpulkan: (1) Agar modul dapat menyentuh hati para mahasiswa perlu adanya contoh konkrit sebagai bahan refleksi berupa cerita-cerita inspiratif tentang kehidupan sehari-hari para mahasiswa, (2) ada kejelasan integrasi dan interkoneksi keilmuannya, dan (3) perlu disusun substansi modelnya, mulai dari filosofi model, konsep dasar, isi, sampai evaluasinya.

\section{Elemen Kultur Pembangnn Karakter}

Berkaitan dengan aktivitas yang diciptakan untuk membangun keyakinan dan nilai-nilai karakter, Thomas Lickona (1991, p.325) meyakini bahwa ada enam elemen kultur yang baik untuk dikembangkan dalam sebuah lembaga pendidikan yaitu: (1) kepemimpinan dan keteladanan moral, (2) kedisiplinan secara menyeluruh, (3) tumbuhnya rasa persaudaraan, (4) suasana demokratis, (5) kerja sama yang harmonis, dan (6) pengagendaan waktu khusus untuk membahas masalah karakter. Enam elemen kultur tersebut sangat relevan dengan modal sosial, dan karenanya diprioritaskan sebagai dasar dalam pengembangan kultur dalam penelitian ini.

\section{Kepemimpinan Moral dan Akademik}

Pada uraian tentang kultur sekolah/ perguruan tinggi, telah disebutkan bahwa perubahan perilaku itu bisa dibangun melalui perubahan konteks (kultur), mengubah situasi, yang akhirnya mengubah perilaku mahasiswa. Dalam konteks ini peran pimpinan memegang peranan yang sangat penting, karena dialah motor penggerak, nahkoda kapal yang mampu memberikan arah kemana "kapal" akan diba- wa mendarat dengan selamat. Walaupun peran pemimpin sangat besar, namun dalam konteks pendidikan nilai tugas membangun kultur bukan semata-mata tugas pimpinan, tetapi peran seluruh warga/anggota kemunitas apapun posisi mereka tetap memegang peranan penting.

Peran pimpinan adalah memberikan visi, kebijakan, mekanisme interaksi, koordinasi dan monitoring. Pilar dari suatu organisasi adalah pemimpin yang selalu fokus untuk memberi (giving-focused), yaitu pemimpin yang memiliki kerendahan hati untuk menghilangkan keakuan (selfless) dan menempatkan kepentingan orang-orang yang dipimpinnya pada posisi terpenting. Pemimpin jenis ini disebut sebagai selfless leader (Yuswohady, 2014, p.3).

Sebaik-baiknya pemimpin adalah jika ia ikhlas dan tidak mementingkan diri sendiri. Pemimpin hebat pasti tidak egois dan tidak mengarahkan tindak-tanduknya melulu untuk kepentingan pribadi (self-centered). Misi terpenting seorang pemimpin bukanlah untuk menuai pujian pribadi, memperoleh promosi pribadi, mendapatkan kekayaan pribadi, meraih kehormatan pribadi, memuluskan kesuksesan karier pribadi, namun yang terpenting adalah melayani orang-orang yang dipimpinnya dan menjadikan mereka lebih baik. Great leader are servants who facilitate the success of others (Yuswohady, 2014, p.3).

Kedisiplinan secara Menyeluruh

Masih dalam bukunya Lickona (2012, p.463) bahwa disiplin adalah unsur penting dalam lingkungan moral. Disiplin menurut Lickona lebih pada disiplin dalam mentaati peraturan yang sedang diberlakukan, bukan sekedar disiplin datang dan pulang kantor saja. Oleh karena itu, untuk mendukung kedisiplinan dalam mentaati aturan atau tata tertib, para peserta didik harus memahami betul apa yang menjadi peraturan di lembaganya. Hal ini sosialisasi terhadap tata tertib harus dilakukan kepada semua unsure yang ada di lembaga pendidikan. Di samping itu, juga dibutuhkan pemantauan dalam implementasi peraturan tersebut.

Tumbuhnya Rasa Persaudaraan

Rasa persaudaraan yang kuat dapat mencegah timbulnya penindasan, kekerasan, dan atau perilaku kasar lainnya. Sebaliknya, 
berbagai persoalan moral, seperti pencurian, penipuan, korupsi akan muncul apabila ikatan persaudaraan lemah, dan norma positif group tersebut tidak ada. Nilai kepedulian, apresiasi, saling monghormati sangat dibutuhkan untuk membentuk rasa perasudaraan, termasuk pertemuan-pertemuan yang sifatnya informal, silaturahim, dan sebagainya. Membiasakan untuk memberi senyum, salam, sapa, sopan, dan santun sangat mendukung tumbuhnya rasa persaudaraan.

Terbangunnya Suasana Demokratis

Lembaga pendidikan yang bersikap terbuka terhadap masukan, pemimpin yang egaliter, keputusan-keputusan dibuat bersama, kegiatan-kegiatan dikerjakan bersama-sama, pemilihan ketua-ketua kelas yang demokratis, serta organisasi mahasiswa yang melibatkan para mahasiswa dalam praktik kepemimpinan yang demokratis dan tanggung jawab.

Terbangunnya Suasana Kerja Sama yang Harmonis

Di dalam masyarakat yang baik, akan tumbuh kerjasama yang baik. Dalam sebuah perguruan tinggi, mereka akan rukun, saling berkolaborasi, bersinergi, baik secara internal maupun eksternal, sehingga mampu meningkatkan mutu intelektualitas dengan temuantemuan atau inovasi yang memiliki kualitas tinggi.

Pengagendaan Waktu untuk Menyelesaikan Persoalan Karakter

Adanya peningkatan kesadaran akan pentingnya moralitas, dengan menyediakan waktu khusus untuk menunjukkan perhatian terhadap moral (Lickona, 2012, p.479). Perhatian bisa ditunjukkan dengan mendalami masalah-masalah merosotnya karakter para anggota komunitas dan mencarikan berbagai alternatif solusinya, sehingga permasalahan tidak meluas.

\section{Hasil Implementasi Model}

Hasil implementasi model ini adalah adanya peningkatan dalam aktualisasi nilainilai karakter mahasiswa. Hal tersebut ditandai dengan pelaksanaan shalat meningkat, terutama frekuensi kelengkapan pelaksanaan shalat lima waktu, shalat-shalat sunah dan shalat malam. Peningkatan tersebut juga diikuti dimensi-dimensi yang lain, yakni: puasa sunah dan ketertiban membaca Al Qur'an terutama mahasiswa yang tinggal di pondok pesantren.

Aktualisasi nilai kejujuran meningkat pada ranah perorangan, namun yang bersifat kolektif dan public service area belum terlihat adanya peningkatan secara berarti. Aktualisasi nilai kepedulian, kerjasama dan tanggung jawab meningkat sangat berarti, hal ini ditandai dengan kesediaan menolong temannya hingga mengalahkan kepentingannya sendiri, menolong temannya walaupun pernah disakiti hatinya, dan kemampuan para mahasiswa menyelenggarakan kegiatan bakti sosial secara mandiri (tanpa bantuan dosen) di Gunung Sumbing dengan empat kegiatan sekaligus: (1) bantuan sembako dan pakaian pantas pakai kepada masyarakat gunung Sumbing, (2) cerdas cermat murid SD, (3) permainan edukatif dan outbond untuk murid SD, dan (4) pemutaran film edukatif untuk warga masyarakat.

Aktualisasi nilai kepedulian, kerja sama, dan tanggungjawab juga meningkat pada lingkungan kos-kosan, ditandai dengan (1) penanganan masalah sampah dengan mengumpulkan dan mengklasifikasi jenis sampah: kertas, plastik, dan kaleng kemudian dijual dan ditabung hasilnya untuk bersama; (2) tertangani masalah ketertiban persuratan tempat tinggal sementara, (3) tertangani masalah etika bersosial mahasiswa yang multikultur, dan (4) peningkatan penanganan ketertiban anak kos dengan menegakkan kembali aturan kos-kosan melalui Perda yang ada dan sosialisasinya.

Melalui analisis kuantitatif, model ini sangat efektif untuk membangun karakter kepedulian dan kerjasama, cukup efektif untuk membangun karakter ketaatan beribadah dan tanggung jawab, dan kurang efektif untuk membangun karakter kejujuran.

\section{SIMPULAN DAN SARAN}

\section{Simpulan}

Dari hasil pembahasan di atas dapat dirumuskan beberapa simpulan penelitian ini yaitu: (1) sebelum implementasi model PKBPMS, aktualisasi nilai-nilai karakter mahasiswa UIN Sunan Kalijaga masih rendah, hal ini ditunjukkan oleh: Radius of trust mereka 
sempit masih terbatas pada kelompoknya/ organisasinya, sebagian mahasiswa menunjukkan sikap dan perlaku mudah putus asa, mudah berbuat anarkhis, mengkonsumsi narkotika, pergaulan bebas, bahkan juga tidak tertib dalam beribadah, (2) pendidikan karakter berbasis penguatan modal sosial melalui tiga pendekatan sesuai untuk membangun karakter mahasiswa UIN Sunan Kalijaga. Pendekatan dimaksud adalah: pertama pendekatan mikro (implementasi modul), kedua pendekatan meso melalui pembangunan kultur lembaga (kampus), dan ketiga pendekatan makro melalui pengembangan jejaring kerja sama, (3) hasil validasi model baik secara kualitatif maupun kuantitatif diperoleh hasil bahwa model telah dinyatakan valid, (4) hasil implementasi model ini secara kualitatif dapat dilihat dari peningkatan aktualisasi nilai-nilai karakter para mahasiswa, baik nilai ketaatan beribadah, kepedulian, kerja sama, tanggung jawab, maupun kejujuran. Aktualisasi nilai kepedulian, kerjasama dan tanggung jawab meningkat sangat berarti ditandai dengan kesediaan menolong temannya hingga mengalahkan kepentingannya sendiri, menolong temannya walaupun pernah disakiti hatinya, dan kemampuan para mahasiswa menghandel kegiatan bakti sosial secara mandiri (tanpa bantuan dosen) di Gunung Sumbing, (5) secara kuantitatif, model ini sangat efektif untuk membangun karakter kepedulian dan kerja sama, cukup efektif untuk membangun karakter ketaatan beribadah dan tanggungjawab, serta kurang efektif untuk membangun karakter kejujuran.

\section{Saran-saran}

Dari kesimpulan tersebut dapat dikemukakan saran sebagai berikut: (1) model pendidikan karakter berbasis penguatan modal sosial (PKBPMS)" terbukti telah dapat meningkatkan aktualisasi nilai-nilai karakter mahasiswa, maka disarankan kepada para pengelola UIN Sunan Kalijaga untuk dapat menerapkan, melanjutkan, bahkan meningkatkan model pendidikan ini, guna membangun karakter para mahasiswa, (2) kolaborasi dan sinergi antara semua pihak baik antarperorangan maupun antarkelompok perlu terus dibina dan ditingkatkan dalam kehidupan keseharian sivitas akademika UIN Sunan Kalijaga melalui kerjasama yang intens, karena hanya dengan cara ini kemajuan sebuah perguruan tinggi dapat ditingkatkan. Sebaliknya, sikap ego sektoral yang hanya mementingkan diri dan kelompok menjadi bumerang terhadap kemajuan pendidikan bahkan dapat merugikan semua pihak., (3) kolaborasi dan sinergi juga perlu terus ditingkatkan antara pengelola berbagai lingkungan pendidikan (lingkungan kampus, keluarga, dan masyarakat) agar terjalin kerja sama yang solid edukatif dalam mengatasi berbagai masalah terkait dengan merosotnya karakter mahasiswa. Upaya yang telah dirintis melalui model ini dengan Program Gerakan Lingkar Kampus UIN Sunan Kalijaga (GELIGA) yang telah dimasukkan dalam program kerja Pusat Pengabdian Masyarakat (PPM) agar dapat terus dipertahankan dan ditingkatkan. Program Temu Wali Mahasiswa Baru yang telah berjalan selama ini perlu terus ditingkatkan manfaatnya untuk mengatasi masalah merosotnya karakter mahasiswa, baik secara preventif maupun kuratif, (4) mengingat pentingnya perhatian, kepedulian, dan kebersamaan bagi pembinaan karakter mahasiswa, maka disarankan kepada Perguruan Tinggi, khususnya UIN Sunan Kalijaga untuk memikirkan sistem boarding sebagai tempat tinggal mahasiswa, khususnya mahasiswa baru.

\section{DAFTAR PUSTAKA}

Ancok, D. (2003). Modal sosial dan kualitas masyarakat. Pidato Pengukuhan Guru Besar pada Fakultas Psikologi, Universitas Gajah Mada, Yogyakarta.

Barliana, Syaom. (2011). Arsitektur, ruang publik, dan pendidikan: Relasi mutual untuk penguatan modal sosial. Pidato Pengukuhan Guru Besar pada Fakultas Pendidikan Teknologi dan Kejuruan, Universitas Pendidikan Indonesia Juni 2011. http://berita.upi.edu/2011/ 06/23/arsitektur-ruang-publik-danpendidikan-relasi-mutual-untukpenguatan-modal-sosial/. Diunduh tanggal 11 April 2012.

Borg, WR. \& Gall MD. (1983). Educational research: an introduction. New York: Longman Inc.

Fukuyama, F. (1995). Trust: The social virtues and the creation of prosperity. London: Hamish Hamilton. 
Karim, M. (2009). Pendidikan kritis transformatif. Yogyakarta: Ar-Ruzz Media.

Kementrian Pendidikan Nasional. (2010). Pengembangan pendidikan budaya dan karakter bangsa: pedoman sekolah. Jakarta: Puskur Balitbang Kemendiknas.

Kedaulatan Rakyat (17 September 2013) dimuat dengan judul "Aktivitas Kuliah Dimulai, Kampus UIN Mirip Pasar”.

Kementerian Pendidikan Nasional Direktorat Jeneral Pendidikan Tinggi (2011). Implementasi pendidikan karakter di perguruan tinggi.

http://www.google.co.id/search?hl=id\&source =hp\&q=model+pendidikan+karakter+ di+perguruan+tinggi, downloaded on July $4^{\text {th }}, 2013$.

Koesoema, A, D. (2010). Pendidikan karakter. strategi mendidik anak di zaman global. Revised Edition. Jakarta: Grasindo.

Lickona, T. (1991). Educating for character: how our school can teach respect and responsibility. New York, Toronto, London, Sydney, Aucland: Bantam books.

Miller, J. P. (1976). Humanizing the classroom. models of teaching in affective education, New York: Praeger Publishers.

Pratama, D. A. (2012). Mengevaluasi sistem pendidikan karakter.

http://www.suaramerdeka.com/v1/index.php/r ead/cetak/2012/08/11/195534/Menge valuasi-Sistem-Pendidikan-Karakter. Downloaded on July $13^{\text {th }}, 2013$.
Putnam, R.D. (1992). The prosperous community: social capital and public life. American prospect, 13, Spring, 35 - 42. In Elinor Ostrom and T.K.

Subiyantoro. (2010). Pengembangan pola pendidikan nilai humanis-religius pada diri siswa berbasis kultural madrasah di MAN Wates Kulon Progo Yogyakarta, disertasi, Yogyakarta: PPs UNY.

Sugiyono. (2006). Metode penelitian pendidikan. (pendekatan kuantitatif, kualitatif, dan R\&D). Bandung: Alfabeta.

Sutrisno. (2011). Pendidikan (agama) Islam berorientasi pada problem subyek didik, Pidato Pengukuhan Jabatan Guru Besar dalam Ilmu Pendidikan Islam, Disampaikan di hadapan Rapat Senat Terbuka Universitas Islam Negeri Sunan Kalijaga, Yogyakarta.

Suyata. (2009). Reinventing education: developing ideal whole person, Paper presented at the International Seminar organized by School of Education UNY, October 10, 2009 in Yogyakarta.

Yuswohady. (2014). Selfless Leader. Koran Sindo Minggu, terbit 16 Maret 2014. Halaman 3.

Zamahsari A. R. (2005). Moral force atau brutal force.

http://www.radarsulteng.com/berita/index.asp ?Berita=Opini\&id=37765. Downloaded on October $21^{\text {st }}, 2012$.

Zuchdi, Darmiyati., dkk. (2009). Pendidikan karakter grand design dan nilai-nilai target. Yogyakarta: UNY Press. 